from most of the rivers where formerly they had abounded, and thousands were seen floating dead down the stream, destroyed apparently by some species of Saprolegnia. It is satisfactory to note that of introduced fish the colonists have now a fine non-migratory trout (brown trout) and a splendid sea-going migratory salmon, the exact species of which is still involved in uncertainty. Among marine fishes special mention is made of the Barracouta (Thyrsites atun) and Kingfish (Th. solandri), which abound all the year round; but there would appear to be next to no attempt to cure the fish for the foreign market. Mr. R. Etheridge contributes a paper on Trilobites and other fossils from the Lower Silurian rocks of the Mersey River district, Tasmania. Several new species are. described, and the species of Trilobites and Brachiopods are figured. Lieut. Beddome describes sixteen new species of Tasmanian shells, and Messrs. Higgins and Petterd some new species of Antechini and Muridæ.

The volume for 1883 contains 65 pages and but few memoirs. Messrs. Higgins and Petterd describe in it some new Tasmanian mice, and the same authors contribute an interesting account of a new cave-inhabiting spider. This species (Theridion troglodytes) was found in a recently-discovered cave in the Chudleigh district. The cave was found to consist of several chambers, in the innermost of which the spiders were found. The floor of the cave is about thirty feet below the level of the present entrance, and is only reached by two well-like descents of from fourteen to sixteen feet each, connected by low passages. There was also found a large deposit of mammalian remains, some in the crevices of the rocks, others embedded in the earthy and stalagmitic floor. These remains can be all referred to non-carnivorous marsupials and mice. It is strange that no insects were found, but the cave would seem to be worth a more detailed investigation, which the authors promise, adding that the stalactites surpassed in beauty those of the well-known Chudleigh Caves.

\section{EXPLORATIONS IN ICELAND}

THE Lava Desert of ÓdáðaHraun

I N about the central region of Iccland, on the northern skirts of Vatnajökull, the largest glacier in Europe, is situated the most extensive occidental lava desert, the Ódádahraun, covering a total area of about 16,000 square miles English. The whole of this wilderness is almost entirely one barren mass of lava, though here and there the traveller may observe patches filled with drifts of sand giving growth to some few stray tufts of upright lymegrass (tlymus arinarius); but frequently a journey may be made through this region for days together without one single blade of grass being sighted. The total absence of vegetation and water in these tracts makes travelling here excessively arduous and risky, and these difficulties are still more aggravated by the elevation of the country above the level of the sea, in consequence of which it may frequently happen, even in the midst of summer, that the traveller is enveloped in blinding snowstorms, which preclude all attempts at further progress while they last. In such predicaments no reliance can be placed on the compass, because of iron entering so very largely into the composition of the lavamasses. Hence this desert has hitherto remained a terra incognita, and has never been surveyed; yet volcanoes of gigantic dimensions are found here, and many natural phenomena beside, which command great scientific interest. Not only to the world of science has Odád̆ahraun been an unknown region, but even the inhabitants of the surrounding country-side have at all times entertained the most vague and ignorant ideas concerning it. For ages they pictured it to themselves as the home of trolls and mountain sprites. Even as late as the present century it was commonly believed that up among the volcanoes there were to be found verdant valleys containing a whole population of outlaws; a belief which took its rise and received its fortification from the fact that jets of steam issuing from the crevassed mountains were taken by distant beholders for smoke ascending from the chimneys of the abodes of outlaws. The outlaws themselves were pictured to the imagination as either human beings of a savage type, or as some preterhuman race of gigantic strength. So firmly ingrained in the people was this belief, that even as late as I 830 an armed expedition was despatched from Mývatn for the purpose of exploring the haunts of these communities of outlaws, the result of which, I need not say, proved discouraging.

In ancient times one of the highways of the country ran across the northern portion of Odáðahraun, which early records show the bishops of Skálholt to have been in the habit of taking on their visitation tours to the east country. This road was used for the last time in 1736 , but has been lost since, and now no one is able to point out its locality and direction. Across the southern portion of the lava no attempt at forcing a passage had ever been made by man until a certain adventurer named Pjetur Brynjúlfsson, in 1794 , succeeded in threading his way from the East Fjörds westward betwcen the lava and the northern spurs of Vatnajökull, until he struck the road of Sprengisand, which traverses the country right across from the northland to the southland quarter. In 1838 Björn Gunnlaugsson, the famous constructor of the best map of Iceland, undertook a journey of exploration to Odádahraun, but fell in with such tempestuous weather that all his attempts at exploration were defeated, and he himself barely escaped with his life. Next year he repeated his journey, and, being favoured with better weather, he forced his way from the south up into the boundary line between the lava and the glacier, and pushed on some distance to the eastward. In this trip he attained some positive results. In I 840 a Danish naturalist, Schythe, intending to explore this region, took the same route, but was overtaken by such excessively stormy weather that, after having lost most of his horses, he just escaped with extreme difficulty into the countryside of Jökuldal in the east country. From this time no attempt at reconnoitring this wild country was hazarded until the stupendous explosion from Askja in 1875 gave such surprising evidence of the enormous activity of the volcanoes in these wildernesses. This year Mr. Watts made his way right across Vatnajökul, striking Askja in his descent over its northern spurs. Shortly afterwards Askja was visited by an Icelander, Jón Thorkelsson, who made his way up to it on foot in the midst of winter. In the summer of 1876 the Danish Government despatched Prof. Johnstrup with a party of scientific men to these volcanic wastes, who explored the region of Askja and constructed a map of the volcanoes. Prof. Johnstrup's is the only scientific exploration that ever yet was carried out in Ódádahraun. At more recent dates Askja has been visited by scveral English tourists, such as Messrs. Lock, Coles, and Morgan. In 1880 several farmers from the districts of Myvatn and Barbardal made the complete circuit of Odá⿱一𫝀hraun. But, in spite of all such reconnoitring trips, the whole of Odádahraun is practically unknown yet, with the exception of the corner occupied by Askja.

Instructed by the Government, I have now for several years been engaged in surveying the upland tracts of Iceland, exploring the country geographically, and examining into its geological structure and character generally, This summer I resolved to attempt an exploration of Ódárahraun with such means as I had at my command. With a view to more expeditiously effecting my purpose, I adopted the plan of sclecting certain fixed stations on grassy spots here and there about the wildernesses which 
surround the lava (the Ódárahraun), and from each of these in turn, as my base of operations, to undertake trips into and about the lava to such a distance as circumstances in each particular case seemed to warrant. To attempt any comprehensive survey of the whole lava at once, the explorer must be supplied with a far larger stock of ponies than I, with my limited means, could muster, and unless such an expedition can carry sufficient fodder for the animals, any lengthened sojourn in one and the same spot is out of the question. But, by the method of exploration that circumstances forced me to adopt, the result must always come short of one's aspirations.

During the first part of July, which I spent in the country-side of Mývatn, I was engaged in examining the volcanoes of the neighbourhood, which for the most part as yet are quite unknown. I also investigated the geology of the country generally, made collections of insects and plants, and ascended the highest mountain peaks in order both to take the bearings of the mountains about Odáðahraun, which are visiblc from Mývatn, and to connect my surveys with such points in the neighbourhood as Björn Gunnlaugsson had formerly fixed trigonometrically. Having finished my outfit and other preparations, I started on July 16 , from the place where I am now writing, for the desert. The weather was cold and threatening, with snow-showers travelling along the higher mountain rises. Our first day's eastward march took us over the mountain called Námafjall into the large wilderness of Mývatnsöræfi, which is bounded on the east by Jökulsá í Axarfirð̀i, the longest river in Iceland. Generally speaking this wilderness is covered with old lavas, which are connected with that of Odádahraun; but plains of drift-sand open here and there, which are studded with hillocks sustaining tufts of Elymus arenarizs. In these wilds are found a great number of craters arranged in rows on defined lines from north to south, many crevasses, and rifts floored with earth at the bottom (jarðföll, i.e. earth-falls, sinks, or dips), which is but what might be expected, where so many lavas have welled forth from the disruptured bowels of the earth. In this locality there occurred a great eruption in 1875 , and in shaping our course to the more southern localities, which were the object of my exploration, we passed close under the northern skirts of the new lava which that eruption created. As the day wore on, a gale of wind arose, and in such a case travelling over these parts ceases to be a pleasure. For some time we had the sand-storm at some distance to the northward before our eyes until it overtook us at last; columnal clouds of brown ashes are whirled into the air, and on joining together in ever increasing numbers the whole view soon becomes enveloped in such dusty darkness that eyesight becomes of little avail ; eyes, nostrils, ears are filled with pulverised sand, which is of such a fineness as to penetrate without difficulty even the traveller's clothes ; drifts of it find their way into the boxes, and gather together under the saddles and the packing gear on the horses: when in contact with the skin it causes great irritation and general discomfort to the body.

As we proceeded through this wilderness, we were struck by the frequent occurrence of horses' bones, in some cases singly, in others in masses, peeping through the sand between the hillocks. This day, by i I o'clock at night, we halted in Fjallagjá, a long glen between two rifts, where we found Elymules arenarius growing in considerable quantity, but no water; it was a troublesome task to secure our tent in the loose drift-sand, but after repeated attempts we succeeded at last in fixing the pegs tolerably securely in the flanks of the hummocks among the interwoven tissues of the roots of the upright lymegrass. In the evening the temperature fell to $30^{\circ} \cdot 2 \mathrm{~F}$., and during the night the earth was covered white with snow; our ponies spent the uncomfortable time in con- stant attempts at running away, which, however, were frustrated by our vigilance. The following morning the same weather continued, still alternating all through the day between sand-storms, snow-showers, hail and sleet squalls. With our view obscured so that we could not take any bearings of the mountains, we still pushed on all day long in a southerly direction, reaching our baitingplace to the south of Her ubreid late at night, in some grass plots along the River Lindaá, a tributary to the above-mentioned Jökulsá, which it joins close on the northern spurs of Herðubreið. The evening came on bitterly cold, and with such a thick fog that even the mountain of Herðubreir in our close neighbourhood was rendered invisible. From this spot, where I remained for a fortnight, I directed my excursions in various directions about the eastern portion of Ódádahraun. Herðubreir is one of the highest mountains in Iceland ( 5290 feet), and of remarkably commanding aspect, terminating, towards the top, in a shoulder of precipitous rocks capped with a cone of perennial ice. This mountain, in spite of repcated attempts, has never yet been ascended. In a north-westerly direction from Heroubreit there arises a mountain-range of considerable length, on a line from south to north, which is called Herdubreidarfjöll or Dyngjufjöll ytri (the outer, i.e. northern, Dyngjufjöll), and is utterly unknown. My first excursions I directed to the examination of these mountains. To the south of this range there rises a great volcano called Dyngja, built up of layers of lava with an inclination of $8^{\circ}$ to $9^{\circ}$ on all sides and rising shield-fashioned to an elevation of 3600 feet; it bears a close resemblance to the famous volcano Skjaldbreid in the south. On the rgth I set out to examine this volcano. Starting in the early morning from my tent on the banks of Lindaá, I had to traverse a lava plateau 1500 feet above the level of the sea, and such was the difficulty of travelling here, that frequently we were on the point of giving up all further attempts it pushing our ponics on, but by dint of perseverance we reached the volcano after a tortuous scramble of fot: hours and a half. The layers of lava forming the slopes of this volcano are excessively rough and of peculiar formation, all split up into fissures from north to south or hollowed out by caves and lava bubbles. Wherever the foot is planted the ground sounds hollow ; in every direction there are innumerable hornitos, seemingly formed originally of a variety of strands of the fiery ooze twisted into all sorts of fantastic shapes, the outer surface suggestive of a tangle of intertwisted snakes of inordinate thickness. When we had made the ascent half way up the mountain, we were overtaken by fog and snowstorm, so that in a short time all objects were hidden out of view and the earth covered with snow. Still in the expectation of the fog clearing away, and the snowstorm blowing over, we went on, and after two hours' brisk walk reached the summit of the volcano. Here all was covered with ice and snow in a temperature of $28^{\circ} \mathrm{F}$. Although the blinding snowstorm prevented anything being seen, I set my theodolite on the chance of the darkness clearing, and had to wait for an hour and a half shivering in the biting blast, when the weather so far cleared that I could take the bearings of several surrounding mountain peaks. This volcano has never been ascended by any man before me, nor would the fact have been passed over in silence, if such had been the case, for even in Iceland the activity of fire has hardly left any traces behind comparable to what is witnessed here. The original crater is 1500 to 1600 feet in diameter, and has, some time subsequent to its first formation, been filled with masses of lava, and now exhibits in the centre a large patch of lava round the circumference of which there stand twelve peak-formed lava columns. In the centre of this plain again there is an enormous crater 400 to 500 fcet in diameter and 600 to 700 feet deep. It is hardly possible to picture to the imagination any sight more stupendous than that which 
opens to view by looking over the verge of this crater down into the precipitous abyss. The crater, with its bottom covered with snow and the sides all whitened with a glacial crust, suggests to the beholder a gigantic cauldron hollowed out in marble. Enormous rocks, which have tumbled down from the brim of the crater, look like minute black specks against the whiteness of the bottom. The composition of the lava is practically entirely basaltic; but reddish rocks of trachyte are strewn about the circumference of the original crater, which shows that sometimes trachytic eruptions have taken place here, as in Askja in I875. When the weather cleared, I had distinctly in view the greater part of Odáðahraun as well as Dyngjufjöll proper, and all the lava currents which have taken their course from the latter complex of volcanoes. In a north-westerly direction from the above-described volcano is another, lower, but quite as wide in circumference, to which we gave the name of Kerlingar-Dyngja. Having surveyed Dyngja, we returned the same way we had come, and reached our tent at half-past two o'clock the next morning.

In a southerly direction from Heroubrei there extends a very considerable mountain range, 3400 feet high, which is called Tögl (Tails) ; it is separated from Herðubrei $r$ by a narrow gate through which, once upon a time, a lava current has found its way. Thus Herðubreir is surrounded by lava on all sides, though that mountain itself is no volcano, but a pile of coarse palagonite breccia interspersed with stray thin layers of basalt throughout its lower parts. One of my excursions I directed to the Tögl. From the tops of these mountains an extensive view opens southward over the sands along the course of Jökulsá and the northern region of Vatnajökull. The aspect of the country to the south of Herðubreid is truly forbidding, all covered with the yellow-gray scoriz from the explosion of Askja in 1875, generally one to two feet in thickness, and no sign anywhere of vegetation. The whole southern horizon exhibits the vast expanse of the snow-white glacial bolsters of Vatnajökull, out of which, in a northerly direction, rises the enormous complex of volcanoes called Kverkfjöll. In some fiery convulsion this mass of mountains has split from end to end, and through the rent a glacier has found its way right down to the level land below. To the west of this rent I observed in the jökull a mass of craters, from one of which huge clouds of white steam ascended into the air. Nothing is known about the volcanic activity in this spot, no one having ever visited those parts of Vatnajökull. On the western side of Kverkfjöll the jökull is one flat ice plateau all the way down to Odádahraun, skirting into a number of moving glaciers terminating in sands and extensive moraines, from which flow innumerable affluents to Jökulsá in Axarfjörd. Towards the east, about the approaches to Sandfell, the next highest mountain in Iceland ( 5800 feet), the jökull exhibits sharp-cut black vertical walls, probably ledges of underlying basaltic belts; but further to the west the flatness of the jökull owes its formation to the substratum bcing made up of palagonite tufa, a softer and more easily ground material. Our western view was determined by a part of Ódádahraun, southern Dyngjufjöll, Askja, and the southern parts of Herðubreiðarfjöll. At the southern termination of Dyngja there rises a very peculiarly formed tufa "fcll," along the crest of which is to be observed a row of a number of vertical tufa peaks, each from one to two hundred feet high, so that the outline of the mountain gives the impression of a gigantic hedgehog.

Next day I set out on the examination of Herdubreiðarfjöll. Directing our course to the north-east, we ascended on our way a mountain by the banks of Jökulsá called Ferjufjall, near which, as the story goes, there was a ferry in those olden times, when the bishops were in the habit of taking that road over the northern skirts of ódázahraun, to which I have alluded already. In a north- westerly direction from this place excessively ancient lavas come to view, which are clearly older even than the Glacial period, exhibiting everywhere large and unmistakable signs of glacial abrasions. In this excursion we came upon a row of those beacons which by general custom in Iceland are erected to point out where roads run through wildernesses. Most of these beacons were but cumuli of stones; one, however, we found still standing, covered with moss and lichens. This we knew now must be the eastern end of the long-lost road, an assumption which subsequent discovery corroborated. As we approached nearer to Herðubreiðarfjöll we came upon a series of craters surrounded by a recent lava, and so rough that no horse might cross it, almost impassable even for a traveller on foot. Leaving our ponies behind, we made our way across this lava, however, as best we could, and reached the highest crest of the mountains shortly before sunset, and enjoyed from it an extensive view. All about these mountains, which are composed of palagonite breccia, there is a number of ridges observable, with small dales and narrow dips scooped out between them, all, however, totally barren of vegetation. About the central portion this range sinks down into low necks honeycombed with many large craters, from which floods of lava have spread over the surrounding country on both sides, east and west, covering an area of some tens of square miles. Having completed my survey of this region, we returned and joined our ponies shortly after midnight, all scratched and lacerated from the lava, with our shoes and stockings in shreds.

Reykjahlíy, near Mývatn, August 4

TH. THORODDSEN

(To be continued.)

\section{THE CONNECTION BETWEEN CHINESE} MUSIC, WEIGHTS, AND MEASURES

CHINESE music can now be heard by all who desire to hear it at the Health Exhibition, and more may be learned on the subject from the pamphlet published by the Commissioners for the Chinese department. A curious account of the common origin of Chinese weights, measures, and musical notes is contained in a paper read some years ago before the German Asiatic Society of Japan by Dr. Wagener. The story is based on native legends, and is also to be found among the Jesuit "Mémoires concernant les Chinois." Dr. Wagener says there is not the slightest doubt that the Chinese system of weights and measures is more than 4600 years old; and it is a highly remarkable circumstance that, quite irrespective of the fact that it is more scientific and exact, it possesses all the advantages for which the French metrical system is so much praised. In the first place, it starts from a basis supplied by Nature; secondly, the decimal arrangement is almost consistently employed throughout; thirdly, linear and dry measure proceed directly from the same unit as the measure of weight; and lastly, what the metrical system does not do, it regulates in the simplest manner the relations of musical notes, which latter form the starting-point for the whole system of weights and measures. The following account of the origin of this system (says Dr. Wagener) contains fact and fancy mingled, but it is easy to distinguish between them. In the reign of the Emperor Hoang-ti, who ruled over China in the twenty-seventh century before Christ, the scholar Lyng-lun was commissioned to complete the musical system which had been discovered 250 years earlier, and particularly to lay down fixed rules for making musical instruments. Naturally he bad to commence with the bamboo, which had already been long used to give the note for other instruments. He therefore betook himself to the province of Siyung in NorthWestern China, where, on the northern slope of a range of 